The capacity of trisaccharides I and II (Nos. 7 and 8, Table 1) to inhibit the agglutination of group B cells by a human anti-B serum was compared with the activity of the five disaccharides isolated from human B substance ${ }^{3}$ (Nos. 2-6, Table 1) and other galactose-containing compounds. The results showed that, on a molar basis, trisaccharide $I$ (No. 7) was twice as active as an inhibitor as the active disaccharide $3-O-\alpha-\mathrm{D}$-galactosyl-D-galactose ${ }^{1}$ (No. 2), whereas trisaccharide II (No. 8) had approximatoly the same activity as the disaccharide and was not more active than the galactotriose (No. 9) isolated from $\lambda$-carrageenin ${ }^{11}$. The difference between the activities of the two trisaccharides from $B$ substance is slight, and trisaccharide II has not yet been obtained in crystalline form, but the results may indicate that the $N$-acetyl-D-glucosamine residue makes a groater contribution to the total activity when joined through a $1 \rightarrow 4$ rather than through a $1 \rightarrow 3$ linkage. The small increase in activity betweon the active disaccharide and the most active trisaccharide suggests that the fourth sugar residue from the non-reducing end of the chain, and other residues still more remote from it, probably contribute little to the total activity. The degree of inhibition given by these oligosaccharide fragments is, however, very small compared with the inhibition given by the intact $\mathbf{B}$ substance and it is possible, as suggested earlier ${ }^{1,4}$, that sugarsattached as branching units to the fragments already isolated may make a significant contribution to the full specificity of the B determinant structure.

We thank Miss Rosalie Morgan for assistance, and the Medical Research Council for financial support.

T. J. PAINTER

WiNIFRED M. WATKINS

W. T. J. Morgan

Lister Institute of Preventive Medicine, Chelsea Bridge Road,

London, S.W.1.

1 Painter, T. J., Watkins, W. M., and Morgan, W. T. J., Nature, 193, 1042 (1962).

${ }^{2}$ Côté, R. H., and Morgan, W. T. J., Nature, 178, 1171 (1956).

3 Painter, T. J., Rege, V. P., and Morgan, W. T. J. (unpublished work). 4 Morgan, W. T. J., Painter, T. J., and Watkins, W. M., Proc. Ninth Cong.
Intern. Soc. Blood Trans., Mexico City, 1962 (in the press).

${ }^{8}$ Dubois, M., Gilles, K. A., Hamilton, J. K., Rebers, P. A., and Smith, F., Anal. Chem., 28, 350 (1956).

- Rondle, C. J. M., and Morgan, W. T. J., Biochem. J., 61.586 (1955).

${ }^{7}$ Peat, S., Whelan, W. J., and Roberts, J. G., J. Chem. Soc., 2258 (1956).

Aminoff, D., Morgan, W. T. J., and Watkins, W. M., Biochem. J., 51, 379 (1952).

'Jeanloz, R. W., and Trémège, M., Fed. Proc., 15, 282 (1956).

${ }^{10}$ Painter, T. J., Chem. Indust., 1214 (1960).

${ }^{1}$ Morgan, K., and O'Neill, A. N., Canad. J. Chem., 3y, 1201 (1959).

${ }^{12}$ Kuhn, R., and Kirschenlohr, W., Chem. Ber., 87, 560 (1954). Zilliken, F., Smith, P. N., Tomarelli, R. M., and Gyorgy, P., Arch. Biochem. Biophys., 54, 398 (1955).

${ }^{23}$ Hough, L., Woods, B. M., and Perry, M. B., Chem. Indust., 1100 (1957).

${ }^{14}$ Kuhn, R., Baer, H. H., and Gauhe, A., Chem. Ber., 87, 1553 (1954).

15 Painter, T. J., Cheese, I. A. F. L., and Morgan, W. T. J., Chem. Indust., 1535 (1962).

\section{Immunoelectrophoresis of Sweat Proteins}

The presence of mucoproteins in human sweat has already beэn described by one of us (M. J.) ${ }^{1}$; mucoproteins were also found in the sweat of the horse, the chief protein of which is albumin (the sweat glands in the horse are of an apocrine type $)^{2,3}$. We have now examined the immunochemical behaviour of proteins in human sweat, according to their spocific antigenic properties.

Using a double-diffusion technique in gel of Ouchterlony ${ }^{4}$, four precipitation lines were found when natural swoat was tested against a rabbit immune serum against sweat protoins (obtained by immunizing a rabbit with protein, which had been isolated from a greater quantity of collected thermal sweat, of a number of normal adults); when normal human serum was tested against the rabbit immune serum against sweat proteins, two precipitation lines were found, According to Ouchterlony's reaction typэs 4 , two of these four protein components in sweat prove to be identical with those present in normal serum, whereas the other two do not.

Using an immunoelectrophoresis microtechnique ${ }^{5}$, five precipitation lines were obtained when the immunoelectrophoretic pattern of sweat was tested with a corresponding rabbit immune serum against sweat proteins (Fig. 1).

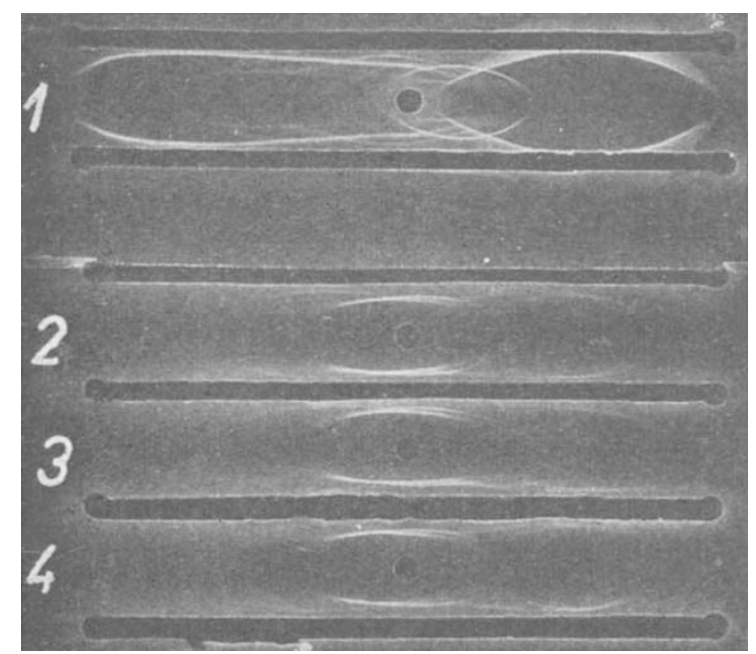

Fig. 1. Immunoelectrophoretic patterns of human sweat in comparison with human serum. 1, Normal human serum (in longitudinal basins a

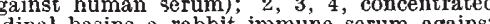
human sweat (in longitudinal basins a rabbit immune serum against
sweat proteins)

At present we are trying to identify the protein components in human sweat and especially their nature as a specific product of the active secretive function of sweat gland cells.

We thank Dr. V. Křižek of the Research Institute of Balneology and Climatology, Mariánské Lázně, for collecting the sweat.

\section{JIRKA}

J. Masopust

Biochemical Department,

Research Institute of Child Development, Faculty of Pediatrics,

Charlos University, Prague.

1 Jirka, M., and Kotas, J., Clin. Chim. Acta, 2, 292 (1957).

2 Evans, C. L., Nisbet, A. M., and Ross, K. A., J. Comp. Path., 67, 397 (1957).

${ }^{3}$ Jirka, M., and Kotas, J., J. Physiol., 147, 74 (1959).

4 Ouchterlony, O., Progress in Allergy, 5, 1 (1958).

'Skvaril, F., Chem. listy, 55, 1069 (1961).

\section{2,6,10,14-Tetramethylpentadecane (Pristane) from Wool Wax}

THE saturated polyisoprenoid hydrocarbon, 2,6,10,14tetramethylpontadecane (pristane), has previously bəen shown to be a constituent of the liver oil of the basking shark (Selache maxima Gunnerus) ${ }^{1,2}$ and a probable constituont of several other elasmobranch fish oils ${ }^{3}$, spormwhale livor ${ }^{4}$ and ambergris ${ }^{5}$. It has more rosently beon identified in a distillate from petroleum crude oils ${ }^{6}$.

Wo have now identified this compound as a constituent of wool wax. The hydrocarbon fraction was obtainod, to the extent of 0.55 por cent, from a sample of the crude wool wax (the wool wax was gonorously provided by $\mathbf{M r}$. Clydo Rowntree, Wellman Combing Co., Johnsonville, S.C.) by alumina chromatography of the hexane-soluble matorials. The normal and less highly branched components wore removed by urea complex formation in $n$-propyl alcohol and the moro highly branched compononts were 